\title{
Sarah Biddulph, Legal Reform and Administrative Detention Powers in China
}

(Cambridge Studies in Law and Society), Cambridge University Press, 2007, xvii+484 pp.

\section{Fu Hualing}

\section{OpenEdition}

\section{Journals}

Electronic version

URL: http://journals.openedition.org/chinaperspectives/4758

DOI: $10.4000 /$ chinaperspectives. 4758

ISSN: 1996-4617

\section{Publisher}

Centre d'étude français sur la Chine contemporaine

\section{Printed version}

Date of publication: 1 December 2008

Number of pages: 111-114

ISSN: 2070-3449

\section{Electronic reference}

Fu Hualing, "Sarah Biddulph, Legal Reform and Administrative Detention Powers in China », China Perspectives [Online], 2008/4 | 2008, Online since 01 December 2008, connection on 23 September 2020. URL : http://journals.openedition.org/chinaperspectives/4758 ; DOI : https://doi.org/10.4000/ chinaperspectives. 4758

This text was automatically generated on 23 September 2020 .

(c) All rights reserved 


\title{
Sarah Biddulph, Legal Reform and Administrative Detention Powers in China
}

\author{
(Cambridge Studies in Law and Society), Cambridge University Press, \\ 2007, xvii+484 pp.
}

\section{Fu Hualing}

1 This book is a timely study of the historical development of, and contemporary debate on, administrative punishment in the People's Republic of China (PRC). Administrative punishment is an intermediary punishment imposed on people who have committed minor offences, as legally defined, and do not deserve criminal punishment. To put intermediary punishment into perspective, one can imagine China's penal regime operating like a gigantic sliding slope as envisaged by Victor $\mathrm{Li}^{1}$ : The vast majority of offences in China are minor and are handled within the community. This first tier of social control intervenes at the earliest signs of deviance, which are handled "softly" through neighbourhood mediation, provision of education and assistance, or police warnings and fines. Intervention at this level is informal, relatively cheap, less stigmatising because of its restorative orientation, and more particularistic so as to better suit the needs of each individual case. A second tier, representing a more formal and "harder" form of intervention, kicks in when community efforts fail to deliver. This is the sphere in which police impose a series of intermediary punishments on a wide range of minor offences for which criminal punishment is deemed unwarranted. The tier of the criminal justice system is reserved for those who have not been saved by earlier interventions and have slid to the bottom of the slope the "incorrigible" individuals who have committed serious offences.

2 The book focuses on three major intermediary punishments in China, including Detention for Education (for prostitutes and their clients, commonly referred to as Women's Education Stations, since the vast majority of inmates are female prostitutes); coercive drug rehabilitation (for drug addicts) and Re-education Through Labour (RTL) (for offenders of minor crimes). 

context by tracing its theoretical/ ideological foundation to the Maoist theory of contradictions, which was (and to some degree is still) the principal guideline for handling social conflict. The PRC was and remains a "democratic dictatorship," which is often interpreted as democracy for the people and dictatorship for the enemy (however defined). Like other revolutionary regimes, the PRC state is characterised by a dual system of justice, one for people who are supportive of the regime and the other for people considered hostile to it. The theory of contradictions justified the creation of a series of non-criminal measures to control minor violation of law when the perpetrators were not class enemies. The reality for the Communists was that "people" who were supportive of the government also committed crimes. Then the question became: are all crimes to be treated as antagonistic contradictions, and are all criminals subject to the dictatorship regardless of their political status?

The Chinese Communist Party (CCP) tried to justify the existence of criminality by arguing that "people" who committed crimes were "the feeble minded who were influenced by hostile foreign and domestic ideologies" and that "crime is left over from the old social system." ${ }^{2}$ But there was a fundamental inconsistency in the government's handling of offences of an apolitical nature. On the one hand, Mao insisted that "people cannot exercise dictatorship over themselves; nor can a part of the people oppress another part," thus limiting the use of the method of dictatorship (i.e. criminal law) against "people" who were led astray and committed crime. On the other hand, Mao also said that "lawbreaking elements among the people should be subjected to punitive legal restraints," but with the qualification that exercising dictatorship over "people" who committed crime was in principle different from exercising dictatorship over the enemies of the people. ${ }^{3}$

11 Intermediary punishment was designed and developed to capture offenders in the twilight zone between the "people" and their "enemies," and between crime and noncrime. It also reflected the contradiction within the theory of contradictions.

Biddulph's book is also successful in highlighting the importance of structural changes in the penal regime. Literature on administrative punishment in China tends to focus on the normative and ideological changes that motivate reform. Normative shifts aside, the author also identifies structural changes in the penal regime that challenge the viability and legitimacy of intermediary punishment. The author rightly points out that great reliance has been placed on intermediary punishment since the early 1980s, as a result of which the system is now over-stretched and fatally strained. 
13 Victor Li was writing about community solidarity and collectivism in the Maoist era, and the "help" he referred to mainly took the form of peer pressure in the community, political persuasion by "significant others," and even warnings by local police. Key to the vision of a gradual sliding into the criminal justice system, which maintained the possibility of early intervention to prevent such sliding, was the existence of a stable social structure in the form of a well-organised community, effective local governance, and a strong rehabilitative and preventative ideology.

14 This communitarian paradigm has faded away and become illusive in the reform period. The kind of community that Victor Li wrote about has largely vanished in the past decades because of urban development, characterised by a sudden increase in migrants and a systematic dismantling of the old neighbourhood structure. There is also a clear shift in the rehabilitative and preventative ideology that underpinned community justice. Intervention at the earliest opportunity becomes much less appealing and legitimate in an age when emphasis is placed firmly on individual freedom and rights in the social and economic spheres. This change has been welldocumented, and its impact on local social order is overwhelming.

15 As a result of this social change, the utility of the traditional first tier of social control has been reduced to little more than a formality. Market reform has narrowed out and thinned the community to such an extent that it no longer has the capacity to absorb disputes and minor violations of law. Without the community serving as a buffer zone for screening out minor problems, police and other formal institutions are pushed to the frontline.

16 The author effectively documents the re-emergence of problems associated with drug use and prostitution and the surge in crime and disorder in general, accompanied by the increasing reliance on the three types of intermediary punishment the book covers. However, the most drastic increase has been in another intermediary punishment that the book does not cover: cases handled according to the Security Administrative Punishment Regulations (SAPR), or the current Security Administrative Punishment Law (SAPL). In 1986, the police accepted slightly more than one million SAPR cases, but the number increased to more than six million in 2006. An equally meaningful demonstration of the connection between the withdrawal of community justice and an increased reliance on formal institutions is the changing ratio between the use of extrajudicial mediation and court adjudication. In the early 1980s, the ratio was 17:1; that is, for every case that went to court, 17 were mediated at the community level. In the 2000s, the ratio became $1: 1{ }^{4}$

Since the community can no longer contain and absorb disputes, there is a much greater demand for police intervention. Without community support, police have to more frequently resort to intermediary punishment in case-handling. Cases that should have been absorbed, and were actu ally absorbed, into the community have become police matters and are given intermediary punishment. With the police becoming more punitive, intermediary punishment is strained, stretched, and distorted in dealing with increasing social conflict as the first resort.

Another challenge that the author touches upon comes from reform in the criminal justice system. Intermediary punishment was justified mainly on the ground that it served as an alternative to harsh, stigmatising criminal punishment, which was reserved for enemies of the state. That may have been true in the PRC's earlier decades, but has no longer been the case since the 1980s: three decades of law reform have 
softened criminal punishment, with the result that the dictatorial nature of criminal law has become much less visible and meaningful. It is well recognised, as the author argues, that the vast majority of cases relate to "contradictions among the people," and that a key principle of criminal law is to educate and rehabilitate.

Over the past three decades, courts have become increasingly lenient in sentencing. In the early 1980s, nearly 40 percent of the defendants were sentenced to terms of not less than five years' imprisonment; that percentage dropped to about 25 percent in 2001. Among defendants who are found guilty by courts after trial, about 20 percent received non-custodial sentences, while all offenders receiving intermediary punishment are incarcerated. ${ }^{5}$ The indisputable fact is that the overlapping jurisdiction between criminal and intermediary punishment is vast and expanding, and the criminal justice system provides more procedural protection than the administrative system. Compared with the ever-improving criminal law, intermediary punishment, which remains unchanged, is harsh in both relative and absolute terms.

Given the contradictions, why is intermediary punishment, especially RTL, still with us? The answers seem straightforward. The police are a powerful political institution in China with overriding political power within the legal system. This institution is loyal to the CCP and plays an instrumental role in safeguarding social order and political stability. As defective as intermediary punishment may be, the police are allowed to retain it, even though other institutions, including the Congress and courts, might prefer to rein in police power. A convenient police argument has been that, since crime and order are a serious problem in China, police need power and resources to bring social order problems under effective control. Police claim they need independent power unsupervised by other legal institutions. For the police, their mission is as noble as it is burdensome.

21 The book's author does a fine job of unpacking the police justification and revealing the hidden institutional and sectoral interests of the police. Yes, the use of intermediary punishment can be politically motivated. RTL in particular has been used to silence political criticism by punishing dissidents who are vocal in criticising the political system, or anyone else who is perceived as posing a challenge to the regime.

Political use of intermediary punishment is limited, however. Given the fact that national security matters are well covered by national security offences in criminal law, the purpose of retaining intermediary punishment cannot be ostensibly political. Police retain intermediary punishment, as the book points out, to advance their own institutional interest. Intermediary punishment is used as a convenient tool by the police to dispose of cases in a more expedient manner and to generate a large amount of financial interest through the imposition of fines. Prostitution, drug use, and gambling are profitable offences, and police want to maintain exclusive control over them. The police are a politically strong organisation, and have been able to elevate their sectoral interest to the level of national interest.

What should be done about intermediary punishment? There is near consensus that intermediary punishment should be placed under effective legal control, including better rules designed to protect rights, effective legal representation, and a fair trial for those who are charged. In the author's view, China should control police power and institutionalise external legal or other oversight. Indeed, the author devotes two lengthy chapters (pp. 223-327) exclusively to discussing the potential and limitations of legal control of the police in general and RTL in particular. The author provides a 
concise, detailed, and useful account of legislative and institutional frameworks that have been put into place to rein in police power. answer is mixed. Law reform as a whole not only regulates and limits police power, but also empowers the police at the same time. It is true that there are more external mechanisms in place to supervise the police, and the mechanisms are more institutionalised. There is the potential or opportunity, as the author argues, for law reform to bring greater police accountability to China. Critics may of course argue that the law and legal framework can also further legitimise and entrench police power. Police remain powerful in spite of, or more accurately, because of the law.

brings us back to the future of administrative punishment. While the book is written in quite positive tones, and the author is confident that the emerging "legal field" will continue to expand, although at a slow pace and through "repetition with a difference" (p. 354), readers may feel more pessimistic after finishing the book. As long as the police are powerful, little can be achieved in controlling them through law reform, and as long as China remains an authoritarian state, the police will continue to be powerful. Perhaps police power and administrative punishment are simply not the place to look for an emerging "legal field."

\section{NOTES}

1. Victor H. Li, Law without Lawyers: A Comparative View of Law in China and the United States, Stanford, Stanford Alumni Association, 1977, p. 39.

2. Jerome A. Cohen, The Criminal Process in the People's Republic of China 1949-1963: An Introduction, Cambridge, Harvard University Press, 1968, p. 78.

3. Ibid., p. 85.

4. Zhang Fusen, “Gonggu wanshan you Zhongguo tese de renmin tiaojia zhidu (To strengthen and improve the system of People's Mediation with Chinese characteristics)," Zhongguo Sifa Pinglun (Chinese Justice Review), vol. 4, 2002, at p. 7. Zhang is a former Minister of Justice.

5. Ibid. 